\title{
Butterfly responses to environmental factors in fragmented calcareous grasslands
}

\author{
Zuzanna M. Rosin • Lukasz Myczko • \\ Piotr Skórka • Magdalena Lenda • Dawid Moroń • \\ Tim H. Sparks $\cdot$ Piotr Tryjanowski
}

Received: 22 December 2010/ Accepted: 8 June 2011/Published online: 22 June 2011

(C) The Author(s) 2011. This article is published with open access at Springerlink.com

\begin{abstract}
Although there is much research showing a strong negative effect of habitat fragmentation and deterioration on the viability of different insect populations and on species richness, the effect of fragmentation is modified by other local and landscape factors. One of the most substantial gaps in knowledge is whether species are similar in their response to the same environmental factors and if their response mirrors response of the entire community. From the conservation point of view this knowledge is of primary importance in planning conservation actions, yet
\end{abstract}

\author{
Z. M. Rosin ( () \\ Department of Cell Biology, Faculty of Biology, Adam \\ Mickiewicz University, Umultowska 89, 61-614 Poznań, Poland \\ e-mail: zuziarosin@o2.pl \\ Ł. Myczko - T. H. Sparks · P. Tryjanowski \\ Institute of Zoology, Poznań University of Life Sciences, \\ Wojska Polskiego 71 C, 60-625 Poznań, Poland \\ P. Skórka \\ Institute of Environmental Sciences, Jagiellonian University, \\ Gronostajowa 7, 30-387 Kraków, Poland \\ M. Lenda \\ Institute of Nature Conservation, Polish Academy of Sciences, \\ Mickiewicza 33, 31-120 Kraków, Poland \\ D. Moroń \\ Institute of Systematics and Evolution of Animals, Polish \\ Academy of Sciences, Sławkowska 17, 31-016 Kraków, Poland \\ T. H. Sparks \\ Fachgebiet für Ökoklimatologie, Technische Universität \\ München, Hans-Carl-von-Carlowitz-Platz 2, 85354 Freising, \\ Germany \\ T. H. Sparks \\ Department of Zoology, University of Cambridge, Downing \\ Street, Cambridge CB2 3EJ, UK
}

these studies are rare. In this paper we test the relative effects of habitat patch and landscape characteristics on butterflies inhabiting calcareous grasslands in southern Poland. Butterfly species richness and abundance were positively affected by patch size and wind shelter. In the case of species richness there was also a positive effect of plant species richness. Butterfly diversity was enhanced in wind sheltered patches, and commonness (non-rarity) enhanced by distance to buildings and by shorter vegetation. Multivariate analysis suggested differences in the responses of individual species to the examined environmental variables, with some species more responsive to patch size and shelter and others to sward height. The conservation of butterfly communities requires sensible and complex management to ensure high habitat diversity. The most important challenge for future studies on calcareous grasslands is to formulate a model of management that guarantees high species richness and conservation of each individual species.

Keywords Community - Conservation · Human settlements $\cdot$ Lepidoptera $\cdot$ Shelter

\section{Introduction}

Habitat fragmentation and deterioration of habitat quality are two of the major threats to biodiversity. Habitat fragmentation leads to a loss of habitat, a reduction of patch size and an increase in patch isolation (Andrén 1994; Fahrig 2003). In western Europe, where habitat fragmentation has reached a high level, studies reporting a decline in insect biodiversity are numerous (e.g. Thomas et al. 2004; Wenzel et al. 2006; Stefanescu et al. 2011). The effect of habitat fragmentation on local population 
dynamics has received attention as the main subject of metapopulation studies (e.g. Thomas et al. 1992; Hanski 1994) and, for practical reasons, the conservation of many species (Hanski and Ovaskainen 2000). According to predictions from metapopulation theory (Levins 1969), patch size and its isolation are the key factors influencing species occurrence, abundance and density in a fragmented landscape (e.g. Hill et al. 1996; Hokit et al. 1999). At the community level it has been demonstrated that fragmented, smaller habitat patches have lower species richness than larger and less isolated ones (Steffan-Dewenter and Tscharntke 2000; Tscharntke et al. 2002). In addition, several field studies focused on the resourcebased concept of habitat indicate that quality of habitat patches may be as important as patch area and isolation (Thomas et al. 2001; Dennis et al. 2003; Dennis and Sparks 2006; Dennis 2010).

The effects of patch size, isolation and quality may also be modified by several other factors such as human disturbance or permeability of the landscape matrix between patches (Tscharntke and Brandl 2004; Grundel and Pavlovic 2007). For example, in areas of high human density some areas may be trampled, littered or the behaviour of butterflies may be modified (Stankowich and Blumstein 2005). Obviously, the permeability of the matrix as well as habitat patch characteristics are now inevitably the result of human activity (Dover and Settele 2009). Some elements in a landscape may be ecological corridors and others may be barriers that enhance and limit, respectively, the dispersal of individuals (Grundel and Pavlovic 2007; Prevedello and Vieira 2009).

Obviously, species differ in their response to changes in the environment. Some species are more vulnerable to habitat fragmentation and others to habitat deterioration, or the species respond differently to the same environmental characteristics (Dover et al. 2011). From the conservation perspective the question of if, and how, species within a community are similar in their response to the same environmental variables is of primary importance (WallisDeVries 1999). High unpredictability in species response to the changes in their environment may cause difficulty in establishing effective conservation procedures, especially when differently responding species are also those of high conservation value. It is astonishing, to some degree, that this problem has only rarely been studied (Shreeve et al. 2001; Dover et al. 2011). In conservation biology there is a prevailing focus on the conservation of individual species or the conservation of total species richness and diversity. Therefore, for well-designed conservation treatments, it is essential to have detailed knowledge about responses to environmental factors of each butterfly species, other co-occurring species, as well as the whole community (Shreeve and Dennis 2011).
One of the vegetation types considered severely threatened due to several human-related changes (e.g. abandonment of management, subsequent invasion of shrubs, high fragmentation due to agriculture intensification, habitat quality changes related to nutrient flow from surrounding farmland) is semi-natural calcareous grassland (Wenzel et al. 2006). In fact, in central Europe, many calcareous grasslands are limited to small isolated patches, often located on hills or limestone outcrops (Krauss et al. 2003; Wenzel et al. 2006). This vegetation type, however, is of leading conservation interest because of a high richness of plant and insect species (Van Swaay 2002; WallisDeVries et al. 2002). Butterflies are considered a model organism for fragmentation studies (New 1991) since they respond relatively quickly to habitat changes (Bourn and Thomas 2002). Finally, butterflies are known to be indicators of habitat quality and 'umbrella' species because conservation of their habitats may also benefit other taxa (New 1991; Thomas et al. 2004).

The aim of this study is to determine the (relative) influence of several environmental factors affecting butterfly species richness, diversity, commonness and individual species in fragmented calcareous grasslands. Based on metapopulation landscape ecology and resource-based concepts, we predict that butterflies should show a higher species richness, probability of presence, and abundance in grasslands that were: (1) larger, (2) less isolated, (3) of higher quality, (4) distant from human settlement, (5) located in a more permeable landscape matrix with higher grassland cover (possibly positively affecting dispersal) and lower forest cover (possible barrier to movements).

\section{Materials and methods}

\section{Study area}

The study was conducted in 32 calcareous grassland patches in southern Poland $\left(50^{\circ} 01^{\prime} \mathrm{N} ; 1^{\circ} 54^{\prime} \mathrm{E}\right), 4-10 \mathrm{~km}$ southwest of Kraków's city centre. The total area covered by calcareous grasslands was 87.3 ha and the study landscape covered ca. $40 \mathrm{~km}^{2}$. Calcareous grasslands were easily distinguishable from the surrounding landscape as they were located on hills adjacent to the flat valley of the River Vistula which is covered mostly by arable land and fallow. At the time of this study all but three calcareous grasslands had been abandoned for about 10-15 years and isolated shrubs were scattered within them. Mowing was noted in two grassland patches: in one a small part $(\sim 20 \%$ of the patch) was mown in late July 2008 and in the second grassland $70 \%$ of its area was mown (twice: in June and in August 2008). We noted also one grassland where goats grazed. 
Butterfly surveys

In all habitat patches we established $5 \mathrm{~m}$-wide transects, on which the presence and abundance of each butterfly species was noted. The length of the transect was proportional to patch area $(\mathrm{r}=0.89, P<0.001)$ and varied between 30 and $960 \mathrm{~m}$ (mean $\pm \mathrm{SE}: 248 \pm 46 \mathrm{~m}$ ). The transects followed a zig-zag pattern within the patch. Three counts were made in each between the 15th July and 20th August 2008 separated by approximately 1 week. Butterflies were surveyed between 09.00 and $16.00 \mathrm{~h}$ during favourable weather conditions (maximum wind: 3 on the Beaufort scale, cloud cover up to $25 \%$, minimum temperature $20^{\circ} \mathrm{C}$ ). The average speed of the transect walk was about $200 \mathrm{~m}$ per $10 \mathrm{~min}$. However, the minimum time spent for counting butterflies was $5 \mathrm{~min}$ in the smallest patches. The order in which the potential habitat patches were recorded was random.

\section{Explanatory and dependent variables}

We measured the following eight environmental variables potentially affecting butterfly populations:

1. Patch size (ha);

2. Isolation; distance to the nearest calcareous grassland (m);

3. Grassland; \% cover of permanent grassland within $500 \mathrm{~m}$ of the patch boundary. Grasslands may act as an ecological corridor or stepping stones enhancing dispersal of the species in calcareous grasslands. For many species in this study, grasslands were also breeding sites;

4. Forest; $\%$ cover of forest within $500 \mathrm{~m}$ of the patch boundary. Forests may act as a barrier to butterfly movements;

5. Buildings; distance to the nearest human settlement (m) as a measure of human activity;

6. Number of plant species as a measure of diversity. 5-10 circular quadrats of $1 \mathrm{~m}$ diameter $\left(0.79 \mathrm{~m}^{2}\right)$ were randomly placed on each transect in July and the cover of each species recorded and averaged per patch (Skórka et al. 2007).

7. Wind shelter. The $\%$ of the patch perimeter protected by forest or shrubs;

8. Vegetation height; mean height $(\mathrm{cm})$ from 10 random measurements per quadrat (see 6 above) and averaged per patch (Skórka et al. 2007).

Environmental variables 1-5 and 7 were calculated with Image J software or directly in the field with the use of a GPS. Variables 6 and 8 were measured during field surveys. The basic characteristics of investigated patches are summarised in Table 1.

Total butterfly species numbers (species richness), the total number of individuals (abundance) and Simpson's Index of Diversity were calculated for each patch. The number of occupied grid squares from the Polish Butterfly Atlas (Buszko 1997) based on field work in 1986-1995 was used to provide a commonness (non-rarity) value for each species. A mean commonness score, weighted by species abundance, was then calculated for each patch. For our recorded species this score could, hypothetically, range from 2 (if only Minois dryas was recorded in a patch) to 784 for Pieris brassicae only. In our patches the mean score varied from 301 to 657 .

Statistical analysis

Forward selection stepwise regression was used to relate the measures of butterfly richness, abundance, diversity and commonness to the eight environmental variables. Variables significant at $0.05<P<0.1$ were retained in these models. A canonical ordination was used to relate the abundance of the individual species to the eight environmental variables using the CANOCO package. Since the length of the longest gradient in DCCA was so short (1.24) we opted to use Redundancy Analysis (a canonical form of PCA) for this ordination. Species data were $\log (x+1)$ transformed before analysis. In addition to Redundancy

Table 1 Basic characteristics of calcareous meadow patches $(n=32)$ in the study landscape

\begin{tabular}{|c|c|c|c|c|c|}
\hline Variables & Variable abbreviation & Mean & SE & Min & Max \\
\hline Patch size (ha) & Patch size & 2.73 & 0.59 & 0.1 & 12.3 \\
\hline Distance to the nearest calcareous meadow (m) & Isolation & 217 & 30 & 43 & 689 \\
\hline Percentage cover of permanent grassland within $500 \mathrm{~m}$ & Grass & 20 & 3 & 2 & 54 \\
\hline Percentage cover of forest within $500 \mathrm{~m}$ & Forest & 28 & 4 & 0 & 80 \\
\hline Distance to the nearest building (m) & Building & 345 & 37 & 32 & 860 \\
\hline Plant species richness & Plant SR & 14.2 & 1.3 & 1 & 33 \\
\hline Wind protection $\%$ & Shelter & 40 & 4 & 12 & 78 \\
\hline Mean height of vegetation $(\mathrm{cm})$ & Veg ht & 23 & 3 & 2 & 57 \\
\hline
\end{tabular}


Analysis, we built presence-absence and abundance models to estimate statistical significance of each environmental variable for each species. Presence-absence data were analysed by generalized linear models with a logit-link function and abundance data were analyzed with stepwise regression. The presence-absence and abundance models were built for species found in at most 27 and at least in five patches, respectively. As before, a forward selection method was used and variables significant at $0.05<P<$ 0.1 were retained in these models.

\section{Results}

General description of the butterfly community

A total of 2,685 individuals belonging to 36 species were observed during transect surveys (Table 2). The most abundant species were Maniola jurtina (15.5\%), Polyommatus icarus (12.2\%), Melanargia galathea (11.5\%), Aphanthopus hyperanthus (10.2\%), Pieris rapae (7.4\%), Thymelicus lineola (6.4\%), Polyommatus coridon (6.3\%), Coenonympha pamphilus (5.3\%) and Aglais io $(5.0 \%)$.

Responses of richness, abundance, diversity and commonness to environmental variables

A summary of the regression models is presented in Table 3. Species richness, abundance and diversity were all positively related to shelter. Butterfly species richness was also positively associated with patch size and plant species richness. Abundance was also positively associated with patch size. The commonness score was positively associated with distance to buildings and negatively with vegetation height suggesting that rarity was greater close to buildings and in the presence of short swards.

\section{Community responses to environmental factors}

The first two axes of the RDA ordination explained 19.2\% of the variation in butterfly species, of which the environmental variables explained $59.5 \%$. The ordination of the species is shown in Fig. 1, where labels for species present in less than 5 patches have been omitted. One group of species appears to be spread in a positive direction along axis 1 and another in a positive direction along axis 2 . The ordination of the eight environmental variables is shown in Fig. 2. This suggests that positive values on axis 1 were associated with larger patches (and to a lesser extent wind shelter and isolation) and positive values on axis 2 with short vegetation.
Presence-absence and abundance models for individual species

Models predicting presence/absence of each species explained on average less variation ( $29 \%, \mathrm{n}=17$ models) than regression models of the abundance of each species $(45 \%, \mathrm{n}=13)$ (Table 2). In presence/absence models, variables that were significant most often included patch size ( six cases), isolation (six), plant species richness (five) and grassland cover within a $500 \mathrm{~m}$ radius (four cases) (Table 2). Moreover, for six species none of the variables significantly explained the presence/absence on transects (Table 2). For 13 species, presence/absence models could not be built due to small sample size (Table 2).

In models predicting butterfly abundance the most important factors appeared to be patch size (six cases) and plant species richness (five). In ten species none of the variables was significant (Table 2). For 13 species, models could not be built due to small sample size (Table 2).

The most consistent influence on species was patch size which positively affected the probability of presence and the abundance of species in most models (Table 3). The species responses to shelter and vegetation height were also consistent in both types of models, however only a few species were affected by these variables (Table 2). For other variables the response of species was highly inconsistent. For example, increasing isolation positively affected the probability of presence of two species but negatively of four other species. Plant species richness positively affected the abundance of three species but negatively for two other species (Table 2).

\section{Discussion}

These results show the importance of habitat patch size in explaining butterfly species richness and abundance in fragmented calcareous grasslands in southern Poland. The models for individual species also showed that patch size was the most frequent variable explaining variation in butterfly presence-absence and abundance in calcareous meadows. These findings are consistent with most studies in north-western Europe on butterfly-patch area relationships (e.g. Steffan-Dewenter and Tscharntke 2000; Krauss et al. 2003; Polus et al. 2007), however some studies also identified that patch size was not a good predictor of population persistence (Pellet et al. 2007). The benefit of large habitat patches for butterfly communities may result not only from its greater size but also from higher colonisation rates and often increased microhabitat diversity (Nowicki et al. 2007).

One of the most interesting results in our study was that shelter played an important positive role in butterfly 
Table 2 Factors affecting the occupancy and abundance of butterfly species in calcareous grasslands (species ranked by abundance)

\begin{tabular}{|c|c|c|c|c|c|c|}
\hline \multirow[t]{2}{*}{ Species } & \multirow{2}{*}{$\begin{array}{l}\text { Number of } \\
\text { occupied patches } \\
\text { (\% occupied) }\end{array}$} & \multirow[t]{2}{*}{ Abundance } & \multicolumn{4}{|l|}{ Factors affecting } \\
\hline & & & Patch occupancy & $\mathrm{R}^{2}$ & Abundance & $\mathrm{R}^{2}$ \\
\hline Maniola jurtina & $22(61)$ & 415 & None & - & $\begin{array}{l}\text { Patch size }(+)^{* * *} \\
\text { Forest }(+)^{* * *} \\
\text { Shelter }(+)^{* * * *} \\
\text { Grass }(+)^{*}\end{array}$ & 0.65 \\
\hline Polyommatus icarus & $22(61)$ & 328 & $\begin{array}{l}\text { Patch size }(+)^{*} \\
\text { Isolation }(-)^{* *} \\
\text { Building }(+)^{*}\end{array}$ & 0.38 & None & - \\
\hline Melanargia galathea & $18(50)$ & 310 & $\begin{array}{l}\text { Patch size }(+)^{\mathrm{a}} \\
\text { Plant SR }(+)^{\mathrm{a}}\end{array}$ & 0.26 & $\begin{array}{l}\text { Patch size }(+)^{* * *} \\
\text { Plant SR }(-)^{* * *} \\
\text { Isolation }(-)^{* *}\end{array}$ & 0.77 \\
\hline Aphanthopus hyperanthus & $22(61)$ & 274 & Plant SR $(-)^{*}$ & 0.18 & Forest $(-)^{*}$ & 0.31 \\
\hline Pieris rapae & $16(44)$ & 198 & Veg ht $(-)^{\mathrm{a}}$ & 0.16 & $\begin{array}{l}\text { Plant SR }(+)^{*} \\
\text { Grass }(-)^{*}\end{array}$ & 0.54 \\
\hline Thymelicus lineola & $17(47)$ & 171 & None & - & Building $(-)^{*}$ & 0.55 \\
\hline Polyommatus coridon & $14(39)$ & 170 & $\begin{array}{l}\text { Patch size }(+)^{*} \\
\text { Building }(-)^{*}\end{array}$ & 0.46 & Patch size $(+)^{\mathrm{a}}$ & 0.41 \\
\hline Coenonympha pamphilus & $20(56)$ & 142 & Shelter $(+)^{\mathrm{a}}$ & 0.14 & None & - \\
\hline Aglais io & $12(33)$ & 135 & Isolation $(+)^{\mathrm{a}}$ & 0.11 & $\begin{array}{l}\text { Patch size }(+)^{\mathrm{a}} \\
\text { Plant SR }(-)^{\mathrm{a}}\end{array}$ & 0.12 \\
\hline Minois dryas & $6(17)$ & 103 & Patch size $(+)^{\mathrm{a}}$ & 0.14 & None & - \\
\hline Vanessa atalanta & $9(25)$ & 83 & $\begin{array}{l}\text { Patch size }(+)^{*} \\
\text { Isolation }(-)^{\mathrm{a}}\end{array}$ & 0.19 & Patch size $(+)^{*}$ & 0.32 \\
\hline Thymelicus sylvestris & $15(42)$ & 61 & None & - & Forest $(-)^{\mathrm{a}}$ & 0.18 \\
\hline Ochlodes sylvanus & $8(22)$ & 38 & $\begin{array}{l}\text { Isolation }(+)^{* *} \\
\text { Grass }(+)^{\mathrm{a}}\end{array}$ & 0.37 & $\begin{array}{l}\text { Plant SR }(+)^{*} \\
\text { Veg ht }(-)^{*}\end{array}$ & 0.77 \\
\hline Erynnis tages & $12(33)$ & 34 & None & - & $\begin{array}{l}\text { Patch size }(-)^{*} \\
\text { Building }(-)^{*}\end{array}$ & 0.60 \\
\hline Araschnia levana & 7 (19) & 31 & None & - & None & - \\
\hline Issoria latonia & $9(25)$ & 27 & $\begin{array}{l}\text { Building }(+)^{\mathrm{a}} \\
\text { Plant SR }(+)^{*}\end{array}$ & 0.38 & $\begin{array}{l}\text { Plant SR }(+)^{*} \\
\text { Shelter }(+)^{\mathrm{a}}\end{array}$ & - \\
\hline Vanessa cardui & $5(14)$ & 26 & $\begin{array}{l}\text { Patch size }(+)^{*} \\
\text { Isolation }(-)^{\mathrm{a}}\end{array}$ & 0.34 & None & - \\
\hline Cupido minimus & $6(17)$ & 24 & Grass $(+)^{\mathrm{a}}$ & 0.25 & None & - \\
\hline Gonepteryx rhamni & 7 (19) & 19 & Plant SR $(+)^{* *}$ & 0.41 & $\begin{array}{l}\text { Building }(+)^{*} \\
\text { Isolation }(+)^{\mathrm{a}}\end{array}$ & 0.27 \\
\hline Lycaena virgaureae & 7 (19) & 19 & $\begin{array}{l}\text { Forest }(-)^{*} \\
\text { Plant SR }(+)^{\mathrm{a}} \\
\text { Grass }(-)^{\mathrm{a}}\end{array}$ & 0.27 & None & - \\
\hline Pieris brassicae & 7 (19) & 17 & $\begin{array}{l}\text { Isolation }(-)^{\mathrm{a}} \\
\text { Forest }(+)^{\mathrm{a}} \\
\text { Shelter }(+)^{\mathrm{a}}\end{array}$ & 0.42 & None & - \\
\hline Papilio machaon & $8(22)$ & 14 & Grass $(-)^{*}$ & 0.26 & None & - \\
\hline Melitaea athalia & $4(11)$ & 14 & - & - & - & - \\
\hline Lycaena phleas & $5(14)$ & 5 & None & - & None & - \\
\hline Argynnis paphia & $2(6)$ & 5 & - & - & - & - \\
\hline Lycaena tityrus & $4(11)$ & 4 & - & - & - & - \\
\hline Argynnis aglaja & $3(8)$ & 4 & - & - & - & - \\
\hline
\end{tabular}


Table 2 continued

\begin{tabular}{|c|c|c|c|c|c|c|}
\hline \multirow[t]{2}{*}{ Species } & \multirow{2}{*}{$\begin{array}{l}\text { Number of } \\
\text { occupied patches } \\
\text { (\% occupied) }\end{array}$} & \multirow[t]{2}{*}{ Abundance } & \multicolumn{4}{|l|}{ Factors affecting } \\
\hline & & & Patch occupancy & $\mathrm{R}^{2}$ & Abundance & $\mathrm{R}^{2}$ \\
\hline Celastrina argiolus & $3(8)$ & 3 & - & - & - & - \\
\hline Aricia agestis & $2(6)$ & 2 & - & - & - & - \\
\hline Melitaea cinxia & $1(3)$ & 2 & - & - & - & - \\
\hline Coenonympha arcania & $2(6)$ & 2 & - & - & - & - \\
\hline Carcharodus alceae & $1(3)$ & 1 & - & - & - & - \\
\hline Thymelicus acteon & $1(3)$ & 1 & - & - & - & - \\
\hline Pontia edusa & $1(3)$ & 1 & - & - & - & - \\
\hline Colias croceus & $1(3)$ & 1 & - & - & - & - \\
\hline Polyommatus dorylas & $1(3)$ & 1 & - & - & - & - \\
\hline
\end{tabular}

Codes for environmental factors: see Table 1; Significance levels: $* P<0.05$; $* * P<0.01$; $* * * P<0.001$; ${ }^{\mathrm{a}} 0.05<P<0.01$. None none of the factors was significant in the model

- indicates that no model was built due to small sample sizes. $(+)$ and $(-)$ indicate positive and negative effects, respectively, of a given variable on the probability of species presence and abundance

Table 3 Significant predictor variables of butterfly species richness, abundance, diversity and commonness from stepwise regression models

\begin{tabular}{lclcr}
\hline Dependent variable & $\mathrm{R}^{2}$ & $\begin{array}{l}\text { Predictor } \\
\text { variable }\end{array}$ & Estimate (SE) & \multicolumn{1}{l}{$P$} \\
& & Patch size & $0.61(0.17)$ & 0.001 \\
Species richness & 0.48 & Shelter & $0.056(0.024)$ & 0.029 \\
& & Plant SR & $0.14(0.07)$ & 0.054 \\
Total number & 0.46 & Patch size & $10.1(2.4)$ & $<0.001$ \\
of individuals & & Shelter & $0.63(0.35)$ & 0.082 \\
Simpson index & 0.10 & Shelter & $0.0013(0.00007)$ & 0.073 \\
Commonness score & 0.36 & Building & $0.20(0.06)$ & 0.003 \\
& & Veg ht & $-2.1(0.9)$ & 0.022 \\
\hline
\end{tabular}

For definition of the variables see Table 1 and "Materials and methods"

species richness, abundance and diversity. At the individual species level this variable also consistently positively affected occupancy and abundance. Wind is a phenomenon that may affect butterfly behaviour (Dover et al. 1997; Brattström et al. 2008), however its direct influence on the foraging behaviour of individuals and community structure is hardly known. Calcareous grasslands in our study area are exposed slopes of hills in a rather flat rural landscape, thus they may be especially exposed to wind. In another study (authors' unpublished data) we noted that, in meadows located in forested areas, various butterfly species were active (frequent flights) on windy days, when butterfly activity in open landscapes was low. Moreover, the edges of calcareous grasslands with trees or shrubs may provide special habitat conditions (e.g. perches) or food resources attractive to some species.

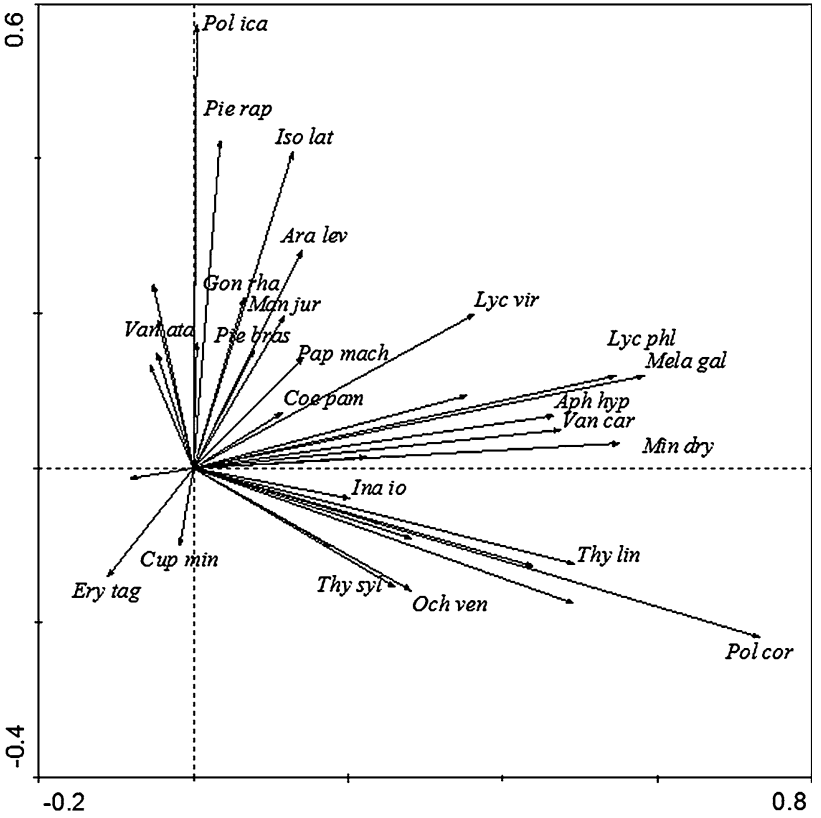

Fig. 1 RDA ordination of 36 butterfly species in 32 habitat patches. Species are identified by abbreviated scientific names. Labels for species occurring in less than five patches have been omitted. The two axes explained $19.2 \%$ of the variation in butterfly numbers

Patch quality, as measured by the number of plant species, was also important for butterfly richness in our study landscape. These results are in line with those from other studies (e.g. Steffan-Dewenter and Tscharntke 2000; Thomas et al. 2001). Moilanen and Hanski (1998) found that immigration increased and emigration reduced in patches containing high densities of flowers. This indicates that additional resources may support larger populations and/or enhance population persistence (Sutcliffe et al. 1997). Thus, 


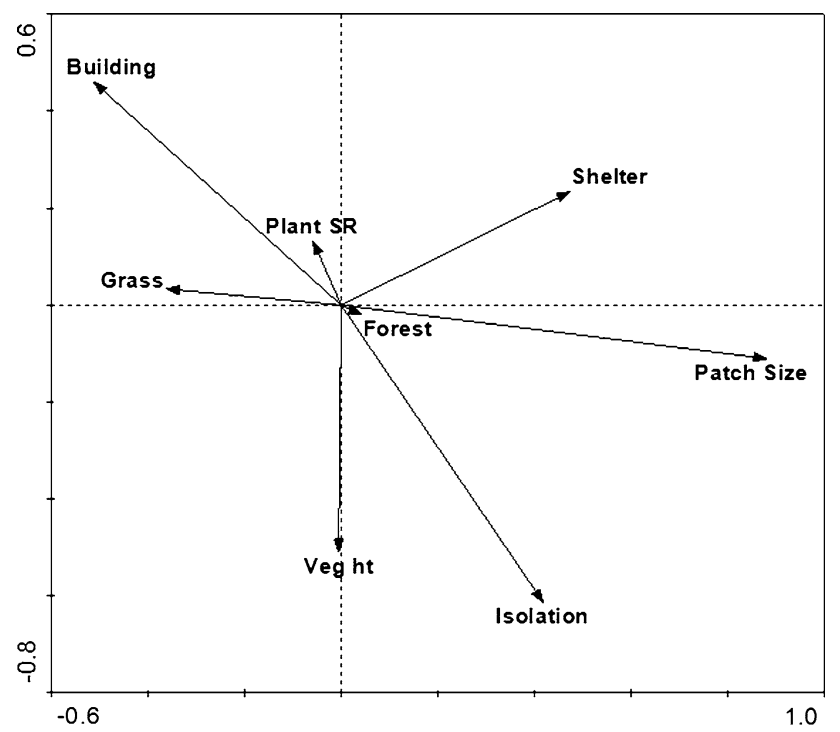

Fig. 2 RDA ordination of eight environmental variables in relation to the butterflies shown in Fig. 1. The environmental variables explained $59.5 \%$ of the variation displayed in Fig. 1

the quality of a patch can, to some extent, act as a substitute for patch area (Hanski and Ovaskainen 2000) and enhance the predictive power of metapopulation models (Thomas et al. 2001). Although occupancy and abundance of several species was positively affected by plant species richness there were a few butterflies (e.g. Aphantopus hyperanthus, Melanargia galathea) which responded negatively to this variable. Larvae of these species are associated with grasses and adult butterflies may prefer areas with a higher cover of grass rather than other plant species.

Another component of habitat quality-vegetation height - had no significant effect on total species richness, abundance or diversity but was important in the ordination of butterfly communities and in explaining differences in commonness and rarity. This suggests that, to successfully protect species inhabiting calcareous grassland, vegetation should be kept at diverse heights within the patch to meet microhabitat requirements of different species, but that shorter swards are critical for some rarer species. This may be achieved by grazing and/or mowing at variable intensity. Such conservation interventions are necessary because currently most of the calcareous grasslands in the study area are abandoned.

The presence of dispersal barriers (forest cover) and potential dispersal corridors (other grassland types) in the surrounding of the habitat patch seemed less important for species richness, total butterfly abundance, diversity and the commonness score. Only at the individual species level were these variables significant for a few species but in an inconsistent way. For example, the abundance of Maniola jurtina was positively affected by both forest and grassland cover in the landscape surrounding the patch whereas the abundances of other species e.g. Aphanthopus hyperanthus, Pieris rapae were negatively affected by forest and grassland cover, respectively. Landscape heterogeneity in the surroundings of habitat patches is known to influence patch connectivity and, in turn, movement patterns (Roland et al. 2000; Tischendorf and Fahrig 2000). Moreover, surrounding grasslands may provide additional food resources for some species and enhance population density and survival rates (Debinski and Holt 2000; Norton et al. 2000). It should also be noted that the proximity of forest might be favourable for butterflies when acting as protection from the wind, enhancing butterfly activity in adverse, windy weather (Dover et al. 1997). Our study indicates that these variables affect individual species rather than total species richness and abundance.

Curiously we found that distance to buildings appeared to be influential on commonness-rarity with higher rarity closer to buildings. Several individual species also had higher occupancy or abundance near human settlements (e.g. Polyommatus coridon, Thymelicus lineola, Erynnis tages). The grasslands close to farms could be those abandoned last and, therefore, probably the most favourable for many rare species associated with short vegetation. It is also possible that people living in the neighbourhood and visiting the patches (most are located in a scenic landscape) may prevent shrub succession to some degree due to trampling and therefore they may create microhabitats for butterflies. Another possibility is that rarer butterflies may benefit from the proximity of human settlement because most of them are single-family houses often possessing flower-rich gardens. Thus, gardens might be a collateral source of nectar for butterflies (Dunning et al. 1992; Ouin et al. 2004). Results from other studies are equivocal; some showed a significant negative effect of human activity on butterfly populations (Kitahara and Fujii 1994; Clark et al. 2007) while others did not find an effect (e.g., Collinge et al. 2003; Nowicki et al. 2007).

\section{Management recommendations and final remarks}

We have shown that species richness, abundance, diversity and commonness are often linked with contrasting environmental variables. This requires conservation actions to balance and manipulate several environmental variables. Moreover, conservation actions may need to be complex because different butterfly species respond differently to the same environmental variables (Dover et al. 2011; Shreeve and Dennis 2011; Williams 2011) and, in effect, these species may show opposing responses to different management treatments (WallisDeVries et al. 2002). Our results strongly support these findings. Therefore, appropriate habitat management depends on the specific aim of conservation of all species since conservation of particular 
species may not necessarily coincide with conservation at the community level and vice versa (WallisDeVries et al. 2002). It has to be borne in mind that conservation action for butterflies in calcareous grassland which is focused on sustaining or improving a specific component of biodiversity (e.g. a high number of species) may not guarantee that other components of biodiversity (e.g. high population sizes or species diversity) will be achieved. Weibull et al. (2000) suggested that to ensure high butterfly species richness and diversity, habitat patches as well as the surrounding landscape should be heterogeneous (Shreeve and Dennis 2011). The results of our study also allow to us to suggest several important management recommendations.

Firstly, our results show that habitat patch size is one of the more important variables influencing species number and abundance. This variable was also important for several individual species. Therefore, maintaining large calcareous grasslands should be the key issue in conservation of butterflies in this habitat. Shelter (low wind) appeared the second most important variable and may be achieved by diversification of grassland edges by planting trees and shrubs and maintaining hedgerows acting as a shelter (Sparks and Parish 1995; Dover et al. 1997; Dover and Sparks 2000). To maintain high plant species richness and protect habitat patches from invasion of shrubs, extensive grazing or mowing should be applied as it is known to increase plant species number (Morris 2000). We propose that maintaining diverse vegetation heights in these grasslands is also important, therefore it may be good practice to apply rotational grazing or mowing (Cremene et al. 2005).

In this study we focused on factors driving different components of butterfly diversity in calcareous grasslands and the response of individual species to habitat and landscape variables. We have shown that the conservation of butterflies involves several variables, often acting in opposing ways, especially at the level of individual species. We think the most important challenge for future studies is to work out a model of management of calcareous grasslands that guarantees conservation of the entire community of insects and plants in this important vegetation type.

Open Access This article is distributed under the terms of the Creative Commons Attribution Noncommercial License which permits any noncommercial use, distribution, and reproduction in any medium, provided the original author(s) and source are credited.

\section{References}

Andrén H (1994) Effects of habitat fragmentation on birds and mammals in landscapes with different proportions of suitable habitat: a review. Oikos 71:355-366

Bourn NAD, Thomas JA (2002) The challenge of conserving butterflies at range margins in Europe. Biol Conserv 104:285292
Brattström O, Kjellén N, Alerstam T, Åkesson S (2008) Effects of wind and weather on red admiral, Vanessa atalanta, migration on coastal site in southern Sweden. Anim Behav 76:335-344

Buszko J (1997) Atlas rozmieszczenia motyli dziennych w Polsce (Lepidoptera: Papilionidae, Hesperiidae). Edycja Turpress: Torun. http://motyle.info/forum/portal2.php?show=rozmieszczenie

Clark PJ, Reed JM, Chew FS (2007) Effects of urbanization on butterfly species richness, guild structure, and rarity. Urban Ecosyst 10:321-337

Collinge SK, Prudic KL, Oliver JC (2003) Effects of local habitat characteristics and landscape context on grassland butterfly diversity. Conserv Biol 17:178-187

Cremene C, Groza G, Rakosy L, Schileyko AA, Baur A, Erhardt A, Baur B (2005) Alterations of steppe-like grasslands in Eastern Europe: a threat to regional biodiversity hotspots. Conserv Biol 19:1606-1618

Debinski DM, Holt RD (2000) A survey and overview of habitat fragmentation experiments. Conserv Biol 14:342-355

Dennis RLH (2010) A resource-based habitat view for conservation. Butterflies in the British landscape. Wiley-Blackwell, Chichester

Dennis RLH, Sparks TH (2006) When is a habitat not a habitat? Dramatic resource use changes under differing weather conditions for the butterfly Plebejus argus. Biol Conserv 129:291-301

Dennis RLH, Shreeve TG, Van Dyck H (2003) Towards a functional resource-based concept for habitat: a butterfly biology viewpoint. Oikos 102:417-426

Dover D, Settele J (2009) The influences of landscape structure on butterfly distribution and movement: a review. J Insect Conserv 13:3-27

Dover JW, Sparks TH (2000) A review of the ecology of butterflies in British hedgerows. J Environ Manage 60:51-63

Dover JW, Sparks TH, Greatorex-Davies JN (1997) The importance of shelter for butterflies in open landscapes. J Insect Conserv 1:89-97

Dover JW, Rescia A, Fungariño S, Fairburn J, Carey P, Lunt P, Arnot C, Dennis RLH, Dover CJ (2011) Land-use, environment, and their impact on butterfly populations in a mountainous pastoral landscape: individual species distribution and abundance. J Insect Conserv 15:207-220

Dunning J, Danielson B, Pulliam H (1992) Ecological processes that affect populations in complex habitats. Oikos 65:169-175

Fahrig L (2003) Effects of habitat fragmentation on biodiversity. Annu Rev Ecol Evol Syst 34:487-515

Grundel R, Pavlovic NB (2007) Resource availability, matrix quality, microclimate, and spatial pattern as predictors of patch use by the Karner blue butterfly. Biol Conserv 135:135-144

Hanski I (1994) A practical model of metapopulation dynamics. J Anim Ecol 63:151-162

Hanski I, Ovaskainen O (2000) The metapopulation capacity of a fragmented landscape. Nature 404:755-758

Hill JK, Thomas CD, Lewis OT (1996) Effects of habitat patch size and isolation on dispersal by Hesperia comma butterflies: implications for metapopulation structure. J Anim Ecol 65: $725-735$

Hokit DG, Stith BM, Branch LC (1999) Effects of landscape structure in Florida scrub: a population perspective. Ecol Appl 9:124-134

Kitahara M, Fujii K (1994) Biodiversity and community structure of temperate butterfly species within a gradient of human disturbance: an analysis based on the concept of generalist vs. specialist strategies. Res Popul Ecol 36:187-199

Krauss J, Steffan-Dewenter I, Tscharntke T (2003) Local species immigration, extinction, and turnover of butterflies in relation to habitat area and habitat isolation. Oecologia 137:591-602

Levins R (1969) Some demographic and genetic consequences of environmental heterogeneity for biological control. Bull Entomol Soc Am 15:237-240 
Moilanen A, Hanski I (1998) Metapopulation dynamics: effects of habitat quality and landscape structure. Ecology 79:2503-2515

Morris MG (2000) The effects of structure and its dynamics on the ecology and conservation of arthropods in British grasslands. Biol Conserv 95:129-142

New TR (1991) Butterfly conservation. Oxford University Press, Oxford

Norton MR, Hannon SJ, Schmiegelow FKA (2000) Fragments are not islands: patch vs landscape perspectives on songbird presence and abundance in a harvested boreal forest. Ecography 23: 209-223

Nowicki P, Pępkowska A, Kudłek J, Skórka P, Witek M, Settele J, Woyciechowski M (2007) From metapopulation theory to conservation recommendations: lessons from spatial occurrence and abundance patterns of Maculinea butterflies. Biol Conserv 140:119-129

Ouin A, Aviron S, Dover J, Burel F (2004) Complementation/ supplementation of resources for butterflies in agricultural landscapes. Agr Ecos Environ 103:473-479

Pellet J, Fleishman E, Dobkin DS, Gander A, Murphy DD (2007) An empirical evaluation of the area and isolation paradigm of metapopulation dynamics. Biol Conserv 136:483-495

Polus E, Vandewoestijne S, Choutt J, Baguette M (2007) Tracking the effects of one century of habitat loss and fragmentation on calcareous grassland butterfly communities. Biodivers Conserv 16:3423-3436

Prevedello JA, Vieira MV (2009) Does the type of matrix matter? A quantitative review of the evidence. Biodivers Conserv 19: $1205-1223$

Roland J, Keyghobadi N, Fownes S (2000) Alpine Parnassius butterfly dispersal: effects of landscape and population size. Ecology 81:1642-1653

Shreeve TG, Dennis RLH (2011) Landscape scale conservation: resources, behaviour, the matrix and opportunities. J Insect Conserv 15:179-188

Shreeve TG, Dennis RLH, Roy DB, Moss D (2001) An ecological classification of British butterflies: ecological attributes and biotope occupancy. J Insect Conserv 5:145-161

Skórka P, Settele J, Woyciechowski M (2007) Effects of management cessation on grassland butterflies in southern Poland. Agr Ecosyst Environ 121:319-324

Sparks TH, Parish T (1995) Factors affecting the abundance of butterflies in-field boundaries in Swavesey Fens, Cambridgeshire, UK. Biol Conserv 73:221-227

Stankowich T, Blumstein DT (2005) Fear in animals: a meta-analysis and review of risk assessment. Proc R Soc L B 272:2627-2634
Stefanescu C, Torre I, Jubany J, Páramo F (2011) Recent trends in butterfly populations from north-east Spain and Andorra in the light of habitat and climate changes. J Insect Conserv 15:83-93

Steffan-Dewenter I, Tscharntke T (2000) Butterfly community structure in fragmented grasslands. Ecol Lett 3:449-456

Sutcliffe OL, Thomas CD, Peggie D (1997) Area-dependent migration by ringlet butterflies generates a mixture of patchy population and metapopulation attributes. Oecologia 109:229-234

Thomas CD, Thomas JA, Warren MS (1992) Distribution of occupied and vacant butterfly habitats in fragmented landscapes. Oecologia 92:563-567

Thomas JA, Bourn NAD, Clarke RT, Stewart KE, Simcox DJ, Pearman GS, Curtis R, Goodger B (2001) The quality and isolation of habitat patches both determine where butterflies persist in fragmented landscapes. Proc R Soc L B 268:1791-1796

Thomas JA, Telfer MG, Roy DB, Preston CD, Greenwood JJD, Asher J, Fox R, Clarke RT, Lawton JH (2004) Comparative losses of British butterflies, birds, and plants and the global extinction crisis. Science 303:1879-1881

Tischendorf L, Fahrig L (2000) On the usage and measurement of landscape connectivity. Oikos 90:7-19

Tscharntke T, Brandl R (2004) Plant-insect interactions in fragmented landscapes. Annu Rev Entomol 49:405-430

Tscharntke T, Steffan-Dewenter I, Kruess A, Thies C (2002) Characteristics of insect populations on habitat fragments: a mini review. Ecol Res 17:229-239

Van Swaay CAM (2002) The importance of calcareous grasslands for butterflies in Europe. Biol Conserv 104:315-318

WallisDeVries MF, Laca EA, Demment MW (1999) The importance of scale of patchiness for selectivity in grazing herbivores. Oecologia 121:355-363

WallisDeVries MF, Poschlod P, Willems JH (2002) Challenges for the conservation of calcareous grasslands in northwestern Europe: integrating the requirements of flora and fauna. Biol Conserv 104:265-273

Weibull A-C, Bengtsson J, Nohlgren E (2000) Butterfly diversity in relation to landscape heterogeneity and farming system. Ecography 23:743-750

Wenzel M, Schmitt T, Weitzel M, Seitz A (2006) The severe decline of butterflies on western German calcareous grasslands during the last 30 years: a conservation problem. Biol Conserv 128: $542-552$

Williams MR (2011) Habitat resources, remnant vegetation condition and area determine distribution patterns and abundance of butterflies and day-flying moths in a fragmented urban landscape, south-west Western Australia. J Insect Conserv 15:37-54 